\title{
Hypercholesterolemia among servers at a public university in Minas Gerais
}

\section{Hipercolesterolemia entre servidores de uma universidade pública mineira}

Janaina Maria Setto Fiorezi ${ }^{1}$, Palmira de Fátima Bonolo ${ }^{2}$, Sylvia do Carmo Castro Franceschini ${ }^{3}$
DOI: $10.5935 / 2238-3182.20140101$

\section{ABSTRACT}

Hypercholesterolemia is an important risk factor for the development of cardiovascular diseases, which represents a public health problem. The aim of this study was to verify the frequency of hypercholesterolemia among servers assisted in the health service of a public university in Minas Gerais. This was a cross-sectional study, with a quantitative approach and data collected in the database of the laboratory of clinical analyzes at the health service. The studied population included 662 servers (teachers and technical and administrative servers) active at the university, from both genders and between 19 and 65 years old. Hypercholesterolemia was present in $51.7 \%$ of the exams with an average age of $52.9 \pm 7.6$ years and average CT value of $205.3 \pm 42.9 \mathrm{mg} / \mathrm{dL}$. A difference in average total cholesterol $(p=0.026)$ and age $(p=0.021)$ was observed. The analysis of the frequency of modifiable cardiovascular risk factors among employees of the institution allows the planning of health care policies for workers.

Key words: Hypercholesterolemia; Cardiovascular Diseases; Occupational Health.

\section{RESUMO}

A hipercolesterolemia é importante fator de risco para o desenvolvimento de doenças cardiovasculares, o que representa problema de saúde pública. O objetivo deste trabalho foi verificar a frequência de hipercolesterolemia entre servidores atendidos em serviço de saúde de uma universidade pública mineira. Trata-se de estudo transversal, de abordagem quantitativa, cujos dados foram coletados no banco de dados do laboratório de análises clínicas do serviço de saúde. A população estudada foi constituída de 662 servidores (docentes e servidores técnico-administrativos) ativos da universidade, de ambos os sexos, de 19 a 65 anos de idade. A hipercolesterolemia esteve presente em 51,7\% dos exames, sendo que a idade média foi de 52,9 \pm 7,6 anos e o valor médio de CT de 205,3 \pm 42,9 mg/dL. Houve diferença de médias de colesterol total $(p=0,026)$ e idade $(p=0,021)$. A análise da frequência de fatores de risco cardiovasculares modificáveis entre trabalhadores de uma instituição possibilita planejar políticas de atenção à saúde do trabalhador.

Palavras-chave: Hipercolesterolemia; Doenças Cardiovasculares; Saúde do Trabalhador.

\section{INTRODUCTION}

Cardiovascular disease (CVD) is the leading cause of morbidity and mortality worldwide. In 2008, ischemic heart disease (12.8\%), strokes (10.8\%), and other cerebrovascular diseases accounted for the main causes of death in the world. ${ }^{1}$ In Brazil, in 2007 , the prevalence of circulatory disease related deaths was $26.9 \%{ }^{2}$
${ }^{1}$ RN. Master degree in Health and Nutrition. Graduate Program in Health and Nutrition, School of Nutrition at the Federal University of Ouro Preto - UFOP. Ouro Preto, $\mathrm{MG}$ - Brazil.

${ }^{2}$ MD. PhD in Public Health. Assistant Professor of Medicine at UFOP. Ouro Preto, MG - Brazil.

${ }^{3}$ Nutritionist. PhD in Sciences. Associate Professor of the Department of Nutrition and Health at the Federal University of Viçosa - UFV. Viçosa, MG - Brazil.
Submitted: 2013/03/28 Approved: 2014/07/30

Institution:

Federal University of Ouro Preto Ouro Preto, MG - Brazil

Corresponding Author: Janaina Maria Setto Fiorezi E-mail: jsetto@enut.ufop.br 
The interaction between risk factors of cardiovascular diseases, including those non-modifiable (age, gender, and family history) and modifiable (amount of body fat, protein-lipid plasma profile, blood pressure levels, diabetes mellitus, smoking, and sedentarism) amplify the risk of developing these diseases. ${ }^{3}$

Hypercholesterolemia has stood out as one of the leading risk factors for the development of CVD along with diabetes mellitus, hypertension, and obesity. ${ }^{4.5}$ It is characterized by cholesterol-rich lipoproteins in the plasma compartment, such as the low density lipoprotein (LDL-C). Several factors can alter cholesterolemia such as genetic predisposition, diet, and body weight. ${ }^{6}$ Obesity and diet that is rich in saturated fats and cholesterol are triggering factors for the highest prevalence in American, European, and Pakistani populations. ${ }^{7}$ Increased fat intake is associated with the elevation of cholesterolemia and high incidence of coronary and aortic atherosclerosis. ${ }^{8}$

In the United States, it is estimated that 1.0 to $3.0 \%$ of deaths from CVD are work-related. ${ }^{9}$ In Brazil, in 2004, DCVs accounted for approximately 300,757 disability retirements and 144,984 temporary disability benefits; $30 \%$ of the estimated number of cases of severe CVD were between 35 and 64 years of age. ${ }^{10}$ Some studies about the prevalence of cardiovascular risk factors were developed with employees from Petrobrás ${ }^{11}$, Spanish workers ${ }^{12}{ }^{13}$ university professors, and university workers indicating that risk factors present in the working environment, such as stress, can alter life habits of workers and potentiate risks for developing cardiovascular disease.

It is possible to reduce risk factors for CVD from the implementation of educational programs with the involvement of nutritionists, physical education teachers, nurses, doctors, and other health professionals with consequent decrease in the occurrence of these diseases and their complications. ${ }^{15}$ The regular monitoring of patients with chronic diseases, such as hypertension and diabetes mellitus, through the formation of educational groups, secured supply and use of medicines, and assistance during complications by multidisciplinary teams is extremely useful in the control of these diseases and improvement of quality of life in this population. ${ }^{16}$

The identification of the prevalence of modifiable risk factors, such as hypercholesterolemia, enables the adoption of strategies to reduce the incidence and prevalence of risk factors and, consequently, of CVD, allowing actions for the establishment of health policies to assist workers based on the development of actions for surveillance, health promotion, and disease prevention.

This study aimed to verify the frequency of hypercholesterolemia among workers assisted in the health service of a public university in Minas Gerais.

\section{METHODS}

This was a cross-sectional study with a quantitative approach performed in the health service of a public university in Minas Gerais. This health service is a primary care clinic that provides basic health care for active workers and retirees, their dependents, and students from the institution; this clinic also performs actions on health promotion and disease prevention in the university community.

The research data were collected in the database from the clinical analyses laboratory in this health service. All testing for total cholesterol (TC) performed in patients 19 years and older, between 2008 and 2010, were analyzed, totaling 2,007 tests.

The study population was made up of 662 workers (professors and technical-administrative workers) active in the institution, from both genders, and aged between 19 and 65 years old.

The determination of TC serum levels in plasma was performed by the laboratory of clinical analyses from the health service upon 12 hours fasting. TC was determined by an enzymatic method, with analysis performed in duplicate, using the equipment Cobas Mira Plus (Roche, USA).

The TC reference levels were defined according to the Brazilian Society of Cardiology (2007) as good cholesterol ( $<200.0 \mathrm{mg} / \mathrm{dL}$ ), borderline cholesterol (200.0 -239.0 mg/dL), and high cholesterol ( $\geq 240.0$ $\mathrm{mg} / \mathrm{dL}$ ) for individuals 19 years and older.

The data were collected in an Excel-XP spreadsheet and analyzed using the SPSS Statistics 17.0 software considering a significance level of $5 \%(p<0.05)$. Descriptive statistics was conducted including simple and relative frequencies, mean and standard deviation. The Student's t-test was used for comparison of means when the variable showed normal distribution; and the Mann-Whitney test when the distribution was not normal.

The research project was approved by the Ethics and Research Committee of the Federal University of Ouro Preto. Because the study used a secondary source of information from an existing database, the 
Institutional Authorization Term and Disclaimer for Data Usage were used as advocated by resolution $n^{\circ}$ 196/96 from the National Health Council.

\section{RESULTS}

A total of 2,007 total cholesterol tests performed in patients 19 years and older, between 2008 and 2010, were analyzed. Hypercholesterolemia, i.e. TC plasma levels $\geq 200.0 \mathrm{mg} / \mathrm{dL}$, was present in 789 tests (39.3\%).

Considering only the test results from active workers $(n=662), 80.2 \%$ were men and $19.8 \%$ were women, with an average age of $52.9 \pm 7.6$ years and average TC value of $205.3 \pm 42.9 \mathrm{mg} / \mathrm{dL}$.

The institution had a total of 3,500 active workers (professors and technical-administrative) during the study period. Among these workers, $13.3 \%$ performed TC tests in the health service. The frequency of hypercholesterolemia among the tests was $51.7 \% ; 51.8 \%$ males and $51.1 \%$ females (Table 1). The frequency of altered tests in males was 55.5, 45.8, and $53.8 \%$ in 2008, 2009, and 2010, respectively. This frequency was $63.2,42.0$, and $47.1 \%$ in females.

Table 1 - Data from workers (19-65 years old) assisted in the health service of a public university, Minas Gerais, 2008 to 2010

\begin{tabular}{|l|c|c|}
\hline \multicolumn{1}{|c|}{ Workers } & $\mathrm{n}$ & $\%$ \\
\hline Total & 3.500 & 100.0 \\
\hline Assisted in the health service & 467 & 13.3 \\
\hline \multicolumn{1}{|c|}{ Tests $(\mathrm{n}=662)$} & $\mathrm{n}$ & $\%$ \\
\hline $\mathrm{CT}<200.0 \mathrm{mg} / \mathrm{dL}$ & 320 & 48.3 \\
\hline $\mathrm{CT} \geq 200.0 \mathrm{mg} / \mathrm{dL}$ & 342 & 51.7 \\
\hline \multicolumn{1}{|c|}{ Males $(\mathrm{n}=531)$} & $\mathrm{n}$ & $\%$ \\
\hline $\mathrm{CT}<200.0 \mathrm{mg} / \mathrm{dL}$ & 256 & 48.2 \\
\hline $\mathrm{CT} \geq 200.0 \mathrm{mg} / \mathrm{dL}$ & 275 & 51.8 \\
\hline \multicolumn{1}{|c|}{$\mathrm{Females}(\mathrm{n}=131)$} & $\mathrm{n}$ & $\%$ \\
\hline $\mathrm{CT}<200.0 \mathrm{mg} / \mathrm{dL}$ & 64 & 48.9 \\
\hline $\mathrm{CT} \geq 200.0 \mathrm{mg} / \mathrm{dL}$ & 67 & 51.1 \\
\hline
\end{tabular}

The higher frequency of workers with hypercholesterolemia, in both genders, was between the ages of 50 to 59 years (Table 2). The average age among hypercholesterolemic men was $53.9 \pm 6.6$ years with mean TC of $238.7 \pm 36.3 \mathrm{mg} / \mathrm{dL}$; the average age among women was $51.3 \pm 8.0$ years and mean TC of $25.1 \pm 227.87$. When it comes to gender, there was no difference between mean ages $(p=0.021)$ and mean total cholesterol $(p=0.026)$, both with non-normal distribution and submitted to the Mann-Whitney test.

Table 2 - Frequency of total cholesterol tests $(\geq 200,0$ $\mathrm{mg} / \mathrm{dL}$ ) in workers (25-65 years old) performed in the health service of a public university, Minas Gerais, 2008 to 2010 .

\begin{tabular}{|l|c|c|c|}
\hline \multicolumn{1}{|c|}{ Age } & Total $\mathrm{n}(\%)$ & Males $\mathrm{n}(\%)$ & Females $\mathrm{n}(\%)$ \\
\hline 25-39 years old & $13(3.8)$ & $05(1.8)$ & $08(11.9)$ \\
\hline 40-49 years old & $70(20.5)$ & $53(19.3)$ & $17(25.4)$ \\
\hline $50-59$ years old & $189(55.3)$ & $155(56.4)$ & $34(50.7)$ \\
\hline $60-65$ years old & $70(20.5)$ & $62(22.5)$ & $08(11.9)$ \\
\hline Total & $342(100.0)$ & $275(100.0)$ & $67(100.0)$ \\
\hline
\end{tabular}

\section{DISCUSSION}

Hypercholesterolemia was present in $51.7 \%$ of the studied population. This percentage closely resembles those found in studies with adult Brazilian population, which indicate hypercholesterolemia prevalence between 26.0 and $56.0 \%$. ${ }^{5,9,17-21}$

The results of the study Atlas Corações do Brasil indicated that the highest prevalence of hypercholesterolemia was found in the southern population with $24.3 \%$. In the Northeast, high levels of cholesterol were present in $21.5 \%$ of the population, similar to that of the Southeastern region with $21.2 \%$. However, the Midwestern and Northern regions showed the lowest prevalence, representing $20.0 \%$ of the population. Therefore, it was found that dietary habits and practice of physical activity related to regional and cultural factors can influence lipid profiles. ${ }^{22}$

The frequency of hypercholesterolemia in this population was greater than that indicated by the Brazilian Society of Cardiology. ${ }^{22}$ However, it is necessary to consider that the data from this study were collected in a health service that caters to a large number of the institution's workers.

Thus, this frequency resembles the results of other studies conducted with workers from other educational institutions. The prevalence of hypercholesterolemia observed by Moreira et al. ${ }^{23}$ was $24.8 \%$ among professors at UFV; $30 \%$ among professors from the School of Nursing at UFMG by Xavier et al..$^{24}$; Moreira et al. ${ }^{5}$ verified this frequency as $30.5 \%$ among technical-administrative workers at UFV; Moreira et al. ${ }^{21}$ found it in $42.7 \%$ of professors and technical-administrative workers at UFV; and Palmeira ${ }^{18}$ observed in $36 \%$ of university workers. 
Studies conducted with this category of workers such as by Avila and Marins ${ }^{25}$ with the university community; Conceição et al., ${ }^{14}$ with university workers; Moreira and Marins ${ }^{13}$ with university professors; and Moreira et al. ${ }^{26}$, with university workers indicated that, besides hypercholesterolemia, this population is constantly exposed to another risk factor, stress.

It is known that the organism responds to stressful situations by activating the autonomic nervous system and hypothalamic-pituitary-adrenal glands axis, which in turn stimulates the release of norepinephrine, epinephrine, and cortisol. This response triggers changes in the functioning of systems, especially in the cardiovascular, gastrointestinal, immune, reproductive, and lipid and glucose metabolism systems, among others. Stress is an important cardiovascular risk factor because it enables the aggravation of other risk factors. ${ }^{27}$

Individuals with high TC levels, regardless of the overall risk, should be instructed to adopt non-pharmacological measures such as low-cholesterol diets and physical activities. ${ }^{28}$

The majority of all studied workers (25-65 years old) with changes in lipid levels were among those in the age range between 50 and 59 years old, of genders (55.3\%). Epidemiological studies indicate that the increase in percentages of cholesterol occurs with increasing age. ${ }^{29} \mathrm{Among}$ women, the incidence of coronary artery disease increases in the postmenopausal period. Despite this, the prevalence of this disease is still higher among men. ${ }^{30,31}$

The frequency of repeated tests among patients with normal and altered total cholesterol was 2.1 exam/patient during the analyzed period (2008 to 2010). The study did not examine other variables that may be associated with hypercholesterolemia such as dietary habits, fat intake, and body mass index. However, the obtained results converged to data reported by several authors in other studies conducted with workers at UFV was observed. ${ }^{5,21}$

\section{CONCLUSION}

The study of the prevalence of cardiovascular risk factors among workers of an institution allowed the planning of worker health care policies.

It should be noted that the implementation of actions directed to the promotion of health and prevention of modifiable risk factors allow reducing the incidence and prevalence of cardiovascular diseases.
Consequently, this can reduce CVD mortality, absenteeism, disability retirements, and financial expenses for health plans and/or the Unified Health System that arise from these diseases.

\section{REFERENCES}

1. World Health Organization. The top 10 causes of death: The 10 leading causes of death by broad income group (2008). [Cited 2012 Feb 12]. Available from: www.who.int/mediacentre/factsheets/fs310/en/index.html

2. Sala A, Mendes JDV. Perfil de mortalidade masculina no estado de São Paulo. Bol Epidemiol Paul.2010; 7(82):15.

3. Criqui HM. Epidemiologia da doença cardiovascular. In: Goldman L, Ausiello DA. Tratado de Medicina Interna. $22^{\mathrm{a}}$ ed. Rio de Janeiro: Eselvier; 2005. p. 290-1.

4. Brasil.Ministério da Saúde.Indicadores de mortalidade por doenças circulatórias. Brasília: Ministério da Saúde; 2001. p. 94. [Cited 2012 Mar 20].Available from: http://www.saude.gov.br.

5. Moreira OC, Oliveira CEP,Teodoro BG, Souza GC, Lizardo FB, Santos LA, et al.Fatores de risco de doença cardiovascular em técnicos administrativos da Universidade Federal de Viçosa. Bioscien J Uberlândia. 2009 set/out; 25(5):133-40.

6. Sempos CT, Cleeman JI, Carrol MD. Prevalence of high blood cholesterol among US adults: an up date based on guidelines from the second report of the National Cholesterol. Education Program Adult Treatmet Panel. JAMA. 1993; 269:3009-14.

7. Moura EC, Castrob CM, Mellinc AS, Figueiredo DB. Perfil lipídico em escolares de Campinas, SP, Brasil. Rev Saúde Pública 2000 out; 34(5):499-505.

8. Sociedade Brasileira de Cardiologia. Departamento de Aterosclerose da Sociedade Brasileira de Cardiologia. IV Diretriz Brasileira sobre Dislipidemias e Prevenção da Aterosclerose. Arq Bras Cardiol. 2007 abr; 88(Sup. 1):5.

9. Brasil. Ministério da Saúde do Brasil, Organização Pan-Americana da Saúde no Brasil. Doenças relacionadas ao trabalho: manual de procedimentos para os serviços de saúde. Brasília: Ministério da Saúde; 2001.p. 17.

10. Azambuja MIR, Foppa1 M, Maranhão MFC, Achutti AC. Impacto econômico dos casos de doença cardiovascular grave no Brasil: uma estimativa baseada em dados secundários. Arq Bras Cardiol.2008; 91(3):163-71

11. Matos FDM, Silva NAS, Pimenta AJM, Cunha AJLA. Prevalência dos fatores de risco para doenças cardiovasculares em funcionários do Centro de Pesquisas da Petrobrás. Arq Bras Cardiol.2004; 82(1):1-4.

12. Alegria E, Cordero A, Laclaustra M, Grima A, Leon M, Casanovas $\mathrm{JA}$, et al. Prevalencia del síndrome metabólico em población laboral española: registro MESYAS. Rev Esp Cardiol. 2005; 85(7):797-806.

13. Moreira OC, Marins JCB. Estudo do risco coronariano em professores do Centro de Ciências Biológicas e do Centro de Ciências Humanas da Universidade Federal de Viçosa. Col Pesq Educ Física. 2006 mar; 4(1):405-9. 
14. Conceição TV, Gomes FA, Tauil PL, Rosa TT.Valores de pressão arterial e suas associações com fatores de risco cardiovascular em servidores da Universidade de Brasília. Arq Bras Cardiol. 2006; 86(1):26-31.

15. Da Luz CR, D'Angelo AW, Ladeira MR, Campos RF, Paschoal VA, Nicastro $\mathrm{H}$, et al. Relationship between the practice of physical exercise and risk of cardiovascular diseases. Nutrire Rev Soc Bras Aliment Nutr.2011 ago; 36(2):1-14.

16. Silva TR, Feldmam C, Lima MHA, Nobre MRC, Domingues RZL. Controle de diabetes mellitus e hipertensão arterial com grupos de intervenção educacional e terapêutica em seguimento ambulatorial de uma unidade básica de saúde. Saúde e Sociedade. 2006 set-dez; 15(3):180-9.

17. Cervato AM, Mazzilli RN, Martins IS, Marucci MF. Dieta habitual e fatores de risco para doenças cardiovasculares. Rev Saúde Pública. 1997;31(3):227-35

18. Palmeira CS. Fatores de risco cardiovascular em funcionários de uma instituição de ensino superior.Salvador,2004 [dissertação]. Salvador: Escola de Enfermagem da Universidade Federal da Bahia; 2004.

19. Machado AAN, Pinheiro MHNP, Mihaliuc AR, Batista AB, Medeiros AIA, Prado AFO, et al. Análise dos fatores de risco para o desenvolvimento de doenças cardiovasculares dos homens fortalezenses. Rev Bras Ciênc Mov. 2005; 13(4):299.

20. Viebig RF,Valero MP,Araújo F,Yamada AT,Mansur AJ.Cardiovascular health profile of an adult population from the metropolitan region of São Paulo. Arq Bras Cardiol. 2006; 86(5):353-60.

21. Moreira OC,Oliveira CEP,Marins JCB. Diagnóstico primário de fatores de risco coronarianos em professores e técnicos administrativos do Centro de Ciências Agrárias da UFV.Rev Digital, (Buenos Aires) 2008 nov; 13(126):1-12. [Cited 2012 Jan 20]. Available from: http://www.efdeportes.com.

22. Sociedade Brasileira de Cardiologia. Atlas Corações do Brasil, 2005. [Cited 2012 Jan 20]. Available from: http://educacao.cardiol.br/coracoesdobrasil/default.asp.
23. Moreira OC, Oliveira RAR, Andrade Neto F, Amorim W, Oliveira CEP,Doimo LA, et al.Associação entre risco cardiovascular e hipertensão arterial em professores universitários. Rev Bras Educ Fís Esporte. 2011 jul/set; 25(3):397-406.

24. Xavier FA, Barboza LF, Monteiro AMP, Santos LC, Oliveira DR. Fatores de risco cardiovascular entre docentes de uma universidade pública de Minas Gerais. Reme Rev Min Enferm. 2010 out/ dez; 14(4):465-72.

25. Ávila AA,Marins JCB.Levantamento epidemiológico dos valores de pressão arterial na comunidade universitária da Universidade Federal de Viçosa. Rev Soc Cardiol Estado de São Paulo. $1997 ; 7(2): 22-2$

26. Moreira OC,Roberti NS, Rosado DG,Brito ISS, Oliveira CEP,Marins JCB. Prevalência de Fatores de risco coronarianos em professores e técnicos administrativos do CCE da UFV. In: Anais do XVI Simpósio de Iniciação Científica da UFV,2007.Viçosa:UFV; 2007.

27. Elias LL, Castro M. Controle neuroendócrino do eixo-hipotálamo-hipófise-adrenal. In: Antunes-Rodrigues J, Moreira AC, Elias LLK, Castro M. Neuroendocrinologia básica e aplicada. Rio de Janeiro: Guanabara Koogan; 2005.

28. Brasil. Ministério da Saúde. Secretaria de Atenção à Saúde. Departamento de Atenção Básica. Prevenção clínica de doenças cardiovasculares, cerebrovasculares e renais. Brasília: Ministério da Saúde; 2006.p. 56.

29. Wenger NK. Epidemiology of coronary heart disease in women. Rev Soc Cardiol Estado de São Paulo. 1996; 6:672-80.

30. Gus I, Fischmann A, Medina C. Prevalência dos fatores de risco da doença arterial coronariana no estado do Rio Grande do Sul. Arq Bras Cardiol.2002; 78(5):478-90.

31. Lotufo PA. Epidemiologia da hipertensão arterial sistêmica no Brasil. In: Sociedade de Cardiologia do Estado de São Paulo. SOCESP II - Cardiologia: Atualização e Reciclagem. São Paulo: Atheneu; 1996 